\title{
The effect of ultrasonic disintegration process conditions on the physicochemical characteristics of excess sludge
}

\author{
Malwina Tytła*, Ewa Zielewicz \\ Silesian University of Technology, Poland \\ Faculty of Energy and Environmental Engineering \\ Institute of Water and Wastewater Engineering \\ *Corresponding author’s e-mail: malwina.tytla@polsı.pl, malwina.tytla@ipis.zabrze.pl
}

Keywords: excess sewage sludge, ultrasonic disintegration, disintegration effects, disintegration conditions.

\begin{abstract}
Ultrasonic disintegration, as a method of sludge pre-treatment (before the stabilization process), causes changes in their physicochemical characteristics. The aim of this study was to determine the influence of ultrasonic disintegration conditions (sonication) on the changes in the physicochemical characteristics of sonicated sludge, i.e. an increase in the content of organic substances in the supernatant, sludge dewaterability and flocs structure. Thickened and non-thickened excess sludge from the municipal wastewater treatment plant in Gliwice was disintegrated. The process was conducted, using a high-power disintegrator equipped with a lenticular horn. In order to determine the most favorable conditions, the sewage sludge was sonicated at a wave frequency of $\mathrm{f}=25 \mathrm{kHz}$ (as a function of time), with a different samples volume $\left(\mathrm{V}_{1}=0.5\right.$ and $\left.\mathrm{V}_{2}=1 \mathrm{~L}\right)$ and emitter position of 1 and the $2.5 \mathrm{~cm}$ from the bottom of the chamber in which the process was conducted. The disintegration of sewage sludge was carried out with a specific energy density $\left(E_{V}\right)$ in the range from 10 to $30 \mathrm{kWh} / \mathrm{m}^{3}$. The evaluation of the disintegration effects was based on changes in the physicochemical characteristics of the sludge and/or supernatant at the end of the process, expressed by commonly used and author's disintegration indicators. The best results were obtained for the sludge disintegrated with a volume of $\mathrm{V}_{2}=1 \mathrm{~L}$ and the emitter position of $2.5 \mathrm{~cm}$ from the bottom of the chamber. The study confirms that in various operating conditions of ultrasonic disintegration, there is a possibility for obtaining different effects which may influence the course of anaerobic stabilization and quality of the final products of the process.
\end{abstract}

\section{Introduction}

The population growth, development of new technologies and increase in the efficiency of biological wastewater treatment methods contribute to the increase in the quantity of excess sludge, which constitutes a serious threat to the environment (Bień et al. 2005, Tomczak-Wandzel et al. 2009, Farooq et al. 2009). It is estimated that until 2018, the amount of sludge produced will be around $707000 \mathrm{Mg}_{\mathrm{TSS}}$ (KPGO 2010). In accordance with the Regulation of the Minister of Economy of $8^{\text {th }}$ January 2013, from $1^{\text {st }}$ January 2016 the storage of sewage sludge is prohibited. It is therefore necessary to use methods and technologies which enable a reduction in sludge volume and allow its rational use (for natural or energetic utilization). One of the most recent research problems is the intensification of sludge stabilization, especially methane fermentation due to the possibility of obtaining energy from the biogas. Methane fermentation is currently the most common process used in wastewater treatment plants (Zhang et al. 2007). The intensification of the biological decomposition of organic matter and thus methane fermentation is enhanced by preliminary disintegration of excess sludge directed to digesters. The essence of the disintegration process is breaking cell membranes and the lysis of microorganism cells. This way organic compounds are available as a substrate for living organisms used in the subsequent processes (Müller et al. 1998, Bougrier et al. 2005, Zielewicz 2007, Zhang et al. 2007, Tabatabaie et al. 2008). Ultrasonic disintegration is one of the most common disintegration methods (Neis et al. 2000, Pilli et al. 2011). The process is based on cavitation which results from the changes in the pressure field caused by ultrasonic waves (Śliwiński 2001, Pilli et al. 2011). Disintegration processes are most commonly applied to excess sludge due to observed deterioration in its susceptibility to biological stabilization and the presence of organisms resistant to anaerobic processes (Fukas-Płonka et al. 2006, Zawieja et al. 2013). The advantages of ultrasonic disintegration are the lack of byproducts and necessity to use additional reagents, and the possibility to intervene while the sonication is under way (Zielewicz 2010, Zielewicz 2007, Bień et al. 1995). The factors influencing disintegration i.e. changes of the sludge and supernatant physicochemical characteristics are as follows: frequency, power and intensity, amount of 
energy supplied over time, and geometrical proportions at the sonication area (position of the emitter inside the chamber in which the process is carried out and the thickness of the sludge layer). Furthermore, ultrasonic disintegration also influences the increase in sewage sludge temperature, which is an additional factor enhancing this process (Tiehm et al., 1997, Zawieja et al. 2011). All these factors are set individually in laboratory conditions (Portenlänger 1999, Zielewicz 2007, Pilli et al. 2011).

Due to the fact that so many factors affect the final results of sonication, there is a need to study the conditions of the excess sludge disintegration process in order to obtain the most favorable effects, i.e. an increase in the content of organic substances in the supernatant or changes in the flocs structure which affect the acceleration of the hydrolytic phase in methane fermentation. The use of ultrasonic disintegration as a process of sludge pre-treatment before stabilization enables us to reduce sludge weight, improve dewaterability of fermented sludge and increase biogas production, perceived as a highly economical use of disintegration. Moreover, the application of disintegration in a sludge processing line reduces the size of an installation used for wastewater and sludge treatment, thus decreasing the operating costs related to the operation of the entire wastewater treatment plant (Müller et al. 1998, Bougrier et al. 2005, Podedworna et al. 2008, Farooq et al. 2009, Giemza 2013).

The aim of the study was to determine the influence of excess sludge ultrasonic disintegration conditions, i.e. amount of energy, time of disintegration and geometrical proportion of the sonication area on the results i.e. increase in a content of organic compounds, changes of sludge dewaterability and flocs structure (degree of solid disintegration), as indicators of the disintegration process. The research was carried out at a constant frequency, at a specific range of energy density $\left(E_{V}\right)$ and with a variable geometry of sonication area. The most favorable conditions of the excess sludge ultrasonic disintegration were specified after the process.

\section{Materials and methods}

\section{Materials}

The research material was thickened (T) and non-thickened (NT) excess sludge originating from the municipal wastewater treatment plant (WWTP) in Gliwice (the river basin of an urban-industrial district). The average flow of the WWTP is
$\mathrm{Q}=34675 \mathrm{~m}^{3} / \mathrm{d}$ with population equivalent (PE) of 236,858 (data for 2013). The samples were collected at two specified locations in the sludge processing line: secondary settling tank and mechanical thickener. The sludge was stored at $4^{\circ} \mathrm{C}$. The characteristics of the substrates before ultrasonic disintegration are presented in Table 1.

\section{Analytical methods}

The process of excess sludge ultrasonic disintegration was carried out in a test stand consisting of a high-power ultrasonic disintegrator, equipped with a special gauge to read the real resonant frequency, as well as power and energy consumed by the lenticular horn ("sandwich type"). Emitter diameter was $\mathrm{d}_{\mathrm{E}}=10 \mathrm{~cm}$ (Fig. 1).

Excess sewage sludge was subjected to the ultrasonic disintegration process with a power of $720 \mathrm{~W}$ and a frequency of $\mathrm{f}=25 \mathrm{kHz}$ (conditions established in previous studies). Disintegration of excess sludge was carried out at different ranges of sonication time, i.e. from 25 to $75 \mathrm{~s}$ for a sample volume of $\mathrm{V}_{1}=0.5 \mathrm{~L}$, and 50 to $150 \mathrm{~s}$ for a sample $\mathrm{V}_{2}=1 \mathrm{~L}$. Sonication time was connected with the energy density $\left(E_{V}\right)$, in the range of 10 to $30 \mathrm{kWh} / \mathrm{m}^{3}$. The amount of the specific energy $\left(E_{S}\right)$ related to the concentration of total solids (TS) in the disintegrated excess sewage sludge is shown in Table 2.

The distance between the emitter and the bottom of the treatment chamber was $1 \mathrm{~cm}$ for sample $\mathrm{V}_{1}$ (sludge layer thickness of $2.5 \mathrm{~cm}$ ) and $2.5 \mathrm{~cm}$ for sample $\mathrm{V}_{2}$ (sludge layer thickness of $5 \mathrm{~cm}$ ) (Fig. 2). Disintegration was carried out with the intensity of $U I_{C}=3.6$ and $U I_{E}=9.2 \mathrm{~W} / \mathrm{cm}^{2}$ (referred to the power of generator with respect to the chamber and emitter surface area) and the power density of $U_{D I}=1,4$ and $U_{D 2}=0.7 \mathrm{~W} / \mathrm{cm}^{3}$ for samples $\mathrm{V}_{1}$ and $\mathrm{V}_{2}$, respectively. The treatment chamber was made of steel and its diameter was $d_{C}=16 \mathrm{~cm}$. The values characterizing the ultrasound field and the amount of energy supplied to the process were calculated by the following equations (1-5) (Śliwiński 2001, Tiehm et al. 2001, Neis et al. 2000, Feng et al. 2009):

$$
\begin{gathered}
U I_{C}=\frac{P}{A_{C}}\left(\frac{W}{\mathrm{~cm}^{2}}\right) \\
U I_{E}=\frac{P}{A_{E}}\left(\frac{W}{\mathrm{~cm}^{2}}\right)
\end{gathered}
$$

Table 1. Characteristics of the sludge and supernatant before the process of ultrasonic disintegration

\begin{tabular}{|c|c|c|c|}
\hline Parameter & Unit & Non-thickened sludge & Thickened sludge \\
\hline \multicolumn{4}{|c|}{ Sludge supernatant } \\
\hline $\mathrm{pH}$ & - & 8.0 & 7.9 \\
\hline Chemical Oxygen Demand (COD) & $\mathrm{mg} / \mathrm{L}$ & 31.8 & 44.3 \\
\hline \multicolumn{5}{|c|}{ Sewage sludge } \\
\hline $\mathrm{pH}$ & - & 7.2 & 6.9 \\
\hline $\mathrm{COD}$ & $\mathrm{mg} / \mathrm{L}$ & 14200 & 19400 \\
\hline Total Solids (TS) & $\mathrm{g} / \mathrm{L}$ & 12.2 & 56.3 \\
\hline Volatile Solids (VS) & $\mathrm{g} / \mathrm{L}$ & 8.5 & 41.2 \\
\hline Fixed Solids (FS) & $\mathrm{g} / \mathrm{L}$ & 3.7 & 15.1 \\
\hline Capillary suction time (CST) & $\mathrm{s}$ & 13.0 & 9.0 \\
\hline
\end{tabular}




$$
\begin{gathered}
U_{D}=\frac{P}{V}\left(\frac{W}{\mathrm{~cm}^{3}}\right) \\
E_{V}=\frac{P \cdot t}{V}\left(\frac{\mathrm{kWh}}{\mathrm{m}^{3}}\right) ;\left(\frac{\mathrm{kJ}}{\mathrm{m}^{3}}\right) \\
E_{S}=\frac{P \cdot t}{V \cdot T S} \quad\left(\frac{\mathrm{kWh}}{\mathrm{kg}_{T S}}\right) ;\left(\frac{\mathrm{kJ}}{\mathrm{kg}_{T S}}\right)
\end{gathered}
$$

where:

$U I_{C}-$ ultrasound intensity relative to the surface area of the chamber; $\left[\mathrm{W} / \mathrm{cm}^{2}\right]$,

$U I_{E}-$ ultrasound intensity relative to the surface area of the emitter; $\left[\mathrm{W} / \mathrm{cm}^{2}\right]$,

$U_{D}-$ ultrasound density; [W/ $\left./ \mathrm{cm}^{3}\right]$,

$A_{C}$ - surface area of the chamber in which sludge disintegration was carried out; $\left[\mathrm{cm}^{2}\right]$,

$A_{E} \quad$ - surface area of the emitter; $\left[\mathrm{cm}^{2}\right]$,

$P \quad$ - power of the ultrasonic generator; $[\mathrm{W}] ;[\mathrm{kW}]$,

$V \quad$ - the volume of a sludge sample; $\left[\mathrm{cm}^{3}\right] ;[\mathrm{L}]$,

$t$ - sonication time; [s],

TS - total solids; $\left[\mathrm{kg} / \mathrm{m}^{3}\right]$,

$E_{V}$ - energy density (consumption of energy per volume unit of sludge); $\left[\mathrm{kWh} / \mathrm{m}^{3}\right] ;\left[\mathrm{kJ} / \mathrm{m}^{3}\right]$,

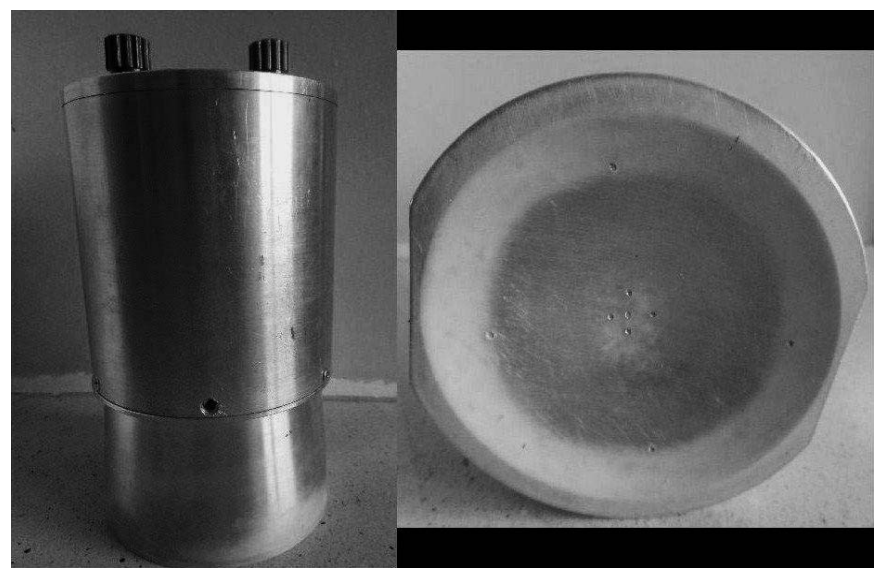

Fig. 1. Lenticular horn
Es - specific energy (consumption of energy per unit of total solids in sludge); $\left[\mathrm{kWh} / \mathrm{kg}_{\mathrm{TS}}\right] ;\left[\mathrm{kJ} / \mathrm{kg}_{\mathrm{TS}}\right]$.

Disintegrated excess sludge was centrifuged at a speed of $20000 \mathrm{rpm}$ over a period of 30 minutes, at a temperature of $18^{\circ} \mathrm{C}$ and subjected to vacuum filtration through cellulose acetate membrane filters with a pore diameter of $0,45 \mu \mathrm{m}$ (Nalgene). In the sludge supernatant (before and after the disintegration process), Chemical Oxygen Demand was assayed spectrophotometrically (Hach Lange tests) and sludge dewaterability was determined, using a kit for measuring the capillary suction time (Envolab) and Whatman 17 paper filter. The excess sludge and supernatant were also examined for $\mathrm{pH}$, total solids, volatile and fixed solids. An observation of the changes in the sludge flocs structure was carried out, using an optical microscope equipped with a camera to capture video (at $100 \times$ magnification). Motic Images Plus 2.0 was used for photo editing. The evaluation of disintegration was performed, using the indicator proposed by Müller (1996), a percentage increase in the examined component value $\left(I_{D(i)}\right.$-authors indicator), and indicator resulting from the changes in the quality of sludge supernatant after ultrasonic disintegration $\left(I_{M(i)}\right)$ (Zielewicz 2007). The above mentioned indicators were specified in the following equations (6-8):

$$
\begin{gathered}
D D=\frac{C O D_{1}-C O D_{2}}{C O D_{3}-C O D_{2}} \cdot 100 \quad(\%) \\
I_{D(i)}=\frac{C_{D}-C_{N D}}{C_{N D}} \cdot 100 \quad(\%) \\
I_{M(i)}=\frac{C_{D}}{C_{N D}}
\end{gathered}
$$

where:

$D D \quad$ - degree of disintegration according to Müller (1996); \%, $C O D_{1}$-supernatant $\mathrm{COD}$ of the disintegrated sample; $\left[\mathrm{mgO}_{2} / \mathrm{dm}^{3}\right]$,

$\mathrm{COD}_{2}$ - supernatant $\mathrm{COD}$ of the original sample (not disintegrated); $\left[\mathrm{mgO}_{2} / \mathrm{dm}^{3}\right]$,

Table 2. The operating conditions of the excess sludge ultrasonic disintegration process

\begin{tabular}{|c|c|c|c|c|c|c|c|c|}
\hline $\begin{array}{c}\text { Energy } \\
\text { density }\end{array}$ & \multicolumn{2}{|c|}{$\begin{array}{c}\text { Sample } \\
\text { volume }\end{array}$} & \multicolumn{2}{c|}{$\begin{array}{c}\text { Sonictaion } \\
\text { time }\end{array}$} & \multicolumn{4}{c|}{ Specific energy $\left(E_{\mathrm{S}}\right)$} \\
\hline$E_{\mathrm{V}}$ & $\mathrm{V}_{1}$ & $\mathrm{~V}_{2}$ & $\mathrm{t}_{1}$ & $\mathrm{t}_{2}$ & \multicolumn{2}{|c|}{$\left.E_{S} \mathrm{~N}_{\mathrm{T}}\right)$} & \multicolumn{2}{c|}{$\left.E_{S_{T}}\right)$} \\
\hline $\mathrm{kWh} / \mathrm{m}^{3}$ & $\mathrm{~L}$ & $\mathrm{~L}$ & $\mathrm{~s}$ & $\mathrm{~s}$ & $\mathrm{kWh} / \mathrm{kg}_{\mathrm{TS}}$ & $\mathrm{kJ} / \mathrm{kg}_{\mathrm{TS}}$ & $\mathrm{kWh} / \mathrm{kg}_{\mathrm{TS}}$ & $\mathrm{kJ} / \mathrm{kg}_{\mathrm{TS}}$ \\
\hline 10 & 0.5 & 1 & 25 & 50 & 0.8 & 3000 & 0.2 & 643 \\
\hline 15 & 0.5 & 1 & 38 & 75 & 1.3 & 4500 & 0.3 & 964 \\
\hline 20 & 0.5 & 1 & 50 & 100 & 1.7 & 6000 & 0.4 & 1286 \\
\hline 25 & 0.5 & 1 & 63 & 125 & 2.1 & 7500 & 0.4 & 1607 \\
\hline 30 & 0.5 & 1 & 75 & 150 & 2.5 & 9000 & 0.5 & 1929 \\
\hline
\end{tabular}



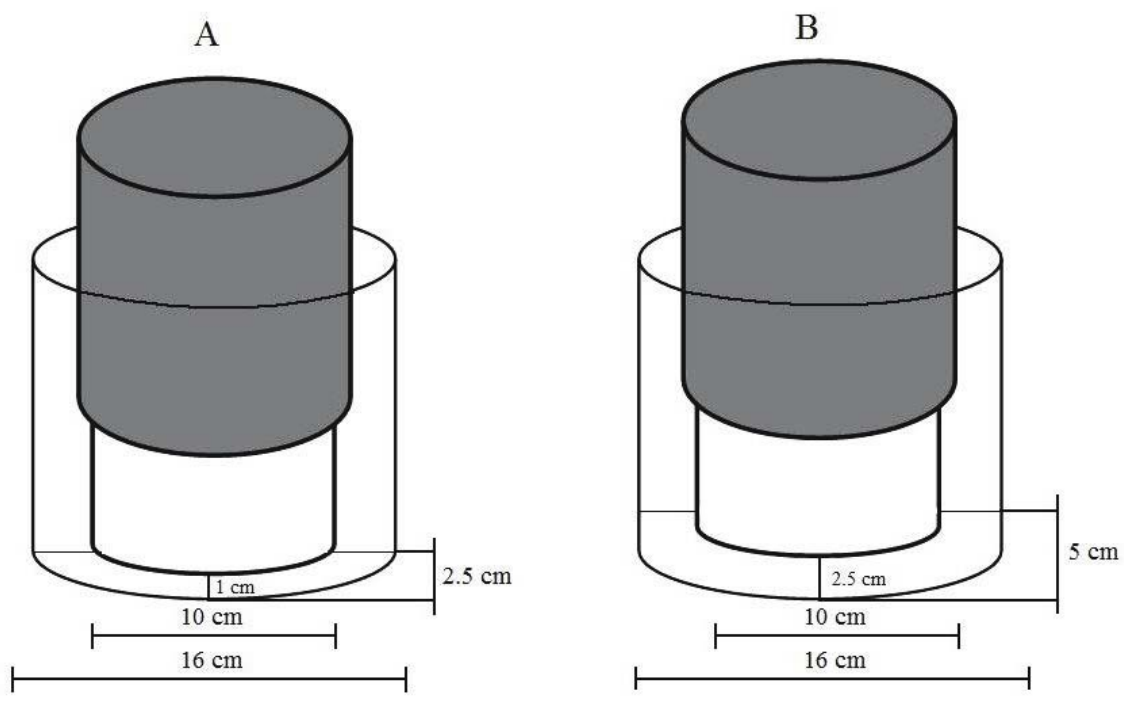

Fig. 2. Geometrical proportions of the emitter and the chamber in the sonication area: $V_{1}$ scheme $(A), V_{2}$ scheme (B)

$\mathrm{COD}_{3}$ - the maximum COD release in the supernatant after chemical disintegration $(0.5 \mathrm{M} \mathrm{NaOH}$, ratio of $1: 1$ for 22 hours at $20^{\circ} \mathrm{C}$ ),

$I_{D(i)} \quad$ - percentage increase of the i-th test compound (indicator of disintegration); [\%],

$C_{D}$ - concentration of a compound in the supernatant of disintegrated sludge; [mg/L]; [s],

$C_{N D}$ - concentration of a compound in the supernatant of non-disintegrated sludge; [mg/L]; [s],

$I_{M(i)} \quad$ - ratio of the $\mathrm{i}$-th test compound value in the sludge or supernatant after ultrasonic treatment to compound value before ultrasonic disintegration (indicator of multiplicity increase).

\section{Results and discussion}

This study determined the influence of ultrasonic disintegration conditions on the results obtained in this process, i.e. changes in the physicochemical characteristics of the examined excess sludge. It has been found that in both non-thickened and thickened sludge the values of all the examined factors increased with an increase in the energy supplied to the process. Thus, it can be concluded that each of them can be used to characterize the effects of sludge disintegration in the ultrasonic field. Furthermore, the amount of the energy density used in the disintegration of non-thickened sludge, converted into the specific energy, was greater than for the thickened sludge characterized by a higher concentration of total solids. However, throughout the study, the amount of energy consumed in the process did not exceed the value of $100000 \mathrm{~kJ} / \mathrm{kg}_{\mathrm{TS}}$ recommended by Kopp et al. (1997) for the operating conditions.

The COD of matter dissolved in the sludge supernatant was used to determine the degree of excess sludge disintegration. Changes in the concentration of the organic substances in the sludge supernatant were used by many researchers as an indicator of disintegration effects (Tiehm et al. 2001, Rai et al. 2004, Bougrier et al. 2005, Zawieja i in. 2013). The degree of disintegration $(D D)$ (according to Eq. 6) was very low. It should be noted that the equation proposed by Müller (1996) refers to the COD concentration obtained as a result of sludge chemical disintegration, using concentrated $\mathrm{NaOH}$. Therefore, in order to achieve a high degree of ultrasonic disintegration, it is necessary to apply a very large amount of energy, which is economically unjustifiable. A higher degree of disintegration was achieved for non-thickened sludge because the energy supplied to the process was not additionally used to break up sludge flocs, as in the case of thickened sludge. The degree of disintegration for the non-thickened sludge was in the range of $0.7-2.0 \%$ and $0.8-3.4 \%$ for sample volumes $V_{1}$ and $V_{2}$ respectively, while the values for the thickened sludge were $0.01-0.09 \%\left(\mathrm{~V}_{1}\right)$ and $0.04-0.13 \%\left(\mathrm{~V}_{2}\right)$. In this study, a higher degree of disintegration was achieved for sludge samples with a lower density power $\left(U_{D 2}\right)$, i.e. for a volume of $V_{2}=1 \mathrm{~L}$. Some investigators have found that the degree of disintegration depends more on the value of power density than the amount of energy supplied to the process, while others consider that relationship as inversely proportional (Wang et al. 2006, Grönroos et al. 2005).

A higher percentage increase in the values of the indicators in the sludge supernatant $\left(I_{D}\right)$, was observed for the emitter position of $2.5 \mathrm{~cm}$ (from the bottom of the chamber) and samples volume of $\mathrm{V}_{1}=1 \mathrm{~L}$, whereas in the case of the sludge samples with a volume of $\mathrm{V}_{1}=0.5 \mathrm{~L}$ characterized by higher power densities, a lower increase was found. This could be due to deep immersion of a horn in the test medium (too small distance from the emitter to the bottom of the chamber), which caused incorrect dispersion of the ultrasonic waves. The results confirmed the impact of the emitter position on the obtained disintegration effects. The authors observed a similar correlation in their previous research concerning the ultrasonic disintegration of sewage sludge in a device of different construction and technical parameters (Tytła et al. 2013). The influence of geometrical proportions in the area of sonication on the effects obtained in the disintegration process were also investigated by other authors (Gogate et al. 2002, Zielewicz 2007).

It has been found that the higher amount of energy supplied to the process increased the COD value (in sludge supernatant) and sludge capillary suction time. A similar 
correlation between the increase in energy input and organic substances growth after the disintegration process was confirmed by Chu et al. (2001) and Show et al. (2007). The increment of COD concentration in the non-thickened sludge supernatant was in the range of: $44-138 \%$ and $55-230 \%$ for $\mathrm{V}_{1}$ and $\mathrm{V}_{2}$ respectively, while for the thickened sludge the values were as follows: $3-23 \%\left(\mathrm{~V}_{1}\right)$ and $9-35 \%\left(\mathrm{~V}_{2}\right)$. It was also concluded that in the case of non-thickened sludge, the energy density of $15-25 \mathrm{kWh} / \mathrm{m}^{3}$ was sufficient to achieve a $100 \%$ increase in COD, while for the thickened sludge it should be above $30 \mathrm{kWh} / \mathrm{m}^{3}$. Higher values of the indicators were observed for non-thickened sludge characterized by the lower concentration of total solids. The influence of a total solids concentration on the effects obtained in the ultrasonic disintegration process was confirmed by other investigators (Show et al. 2007, Zhang et al. 2008), indicating that the most preferred total solids content in the sludge subjected to disintegration should be in the range of 2 to $3 \%$. In this study, the concentration of total solids in excess sludge was over the recommended range, which could have an important influence on the effects obtained. The concentration of organic matter in the supernatant of disintegrated non-thickened (NTD) and thickened sludge (TD), before and after ultrasonic disintegration process is shown in Figs 3 and 4.

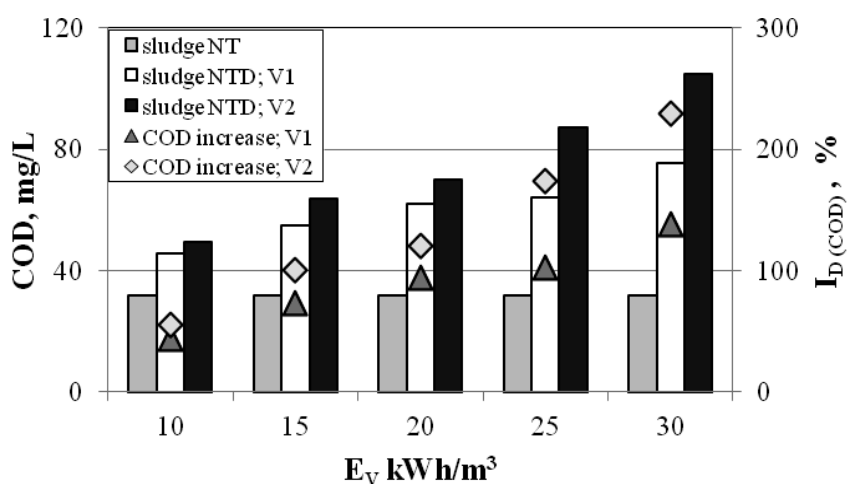

Fig. 3. The influence of energy density on the COD content in the supernatant of non-thickened sludge after the disintegration process

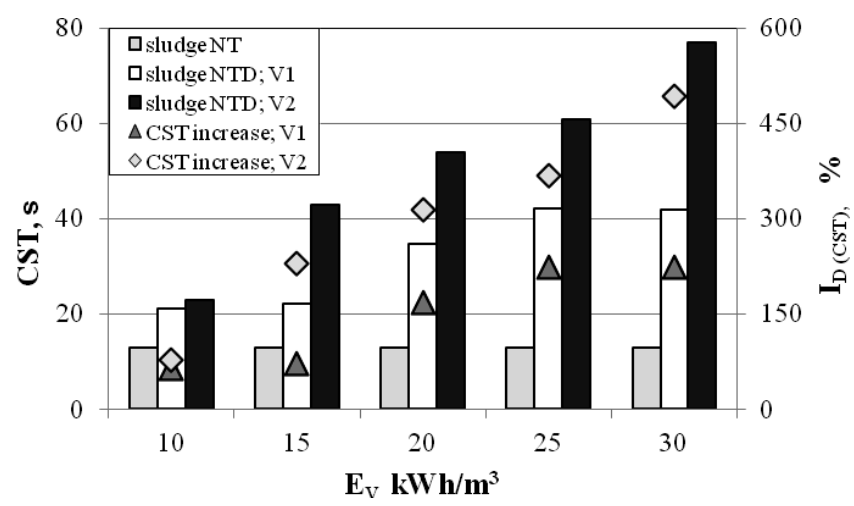

Fig. 5. The influence of energy density on the CST changes in the supernatant of non-thickened sludge after the disintegration process
Literature data (Chu et al. 2001) and results of this research indicate that the increase in the energy input and sonication time deteriorates sludge dewaterability (expressed as an increase in capillary suction time). The capillary suction time for the sludge with good dewaterability is about $20 \mathrm{~s}$ (Dewil et al. 2006). In this study, the CSTs of non-thickened and thickened sludge before the sonication were 13 and 9 s, respectively. The percentage increase in CST values for non-thickened sludge after the disintegration ranged from 63 to $223 \%\left(\mathrm{~V}_{1}\right)$, and 77 to $493 \%\left(\mathrm{~V}_{2}\right)$, while its values for thickened sludge were $85-187 \%\left(\mathrm{~V}_{1}\right)$, and $100-253 \%\left(\mathrm{~V}_{2}\right)$. The deterioration in sludge dewaterability with an increase of sonication time was caused by the reduction in sludge particles (disintegration of the solid phase) and growth in their surface area (which adsorbs water), resulting in an increase in bound water content (Chu et al. 2001, Chen et al. 2001, Dewil et al. 2006, Pilli et al. 2011). Another cause of the sludge dewaterability deterioration (due to the increase in the energy supplied to the process), could also be an increase in extracellular polymeric substances (EPS) in the sludge supernatant. Chen et al. (2001) and Feng et al. (2009) have observed that EPS compounds contribute to the increase in sludge viscosity and form a thin layer on their surface which blocks the water inside the flocs, causing deterioration in sludge dewaterability. The changes of CST values in the excess sludge are shown in Figs 5 and 6. The indicators determining

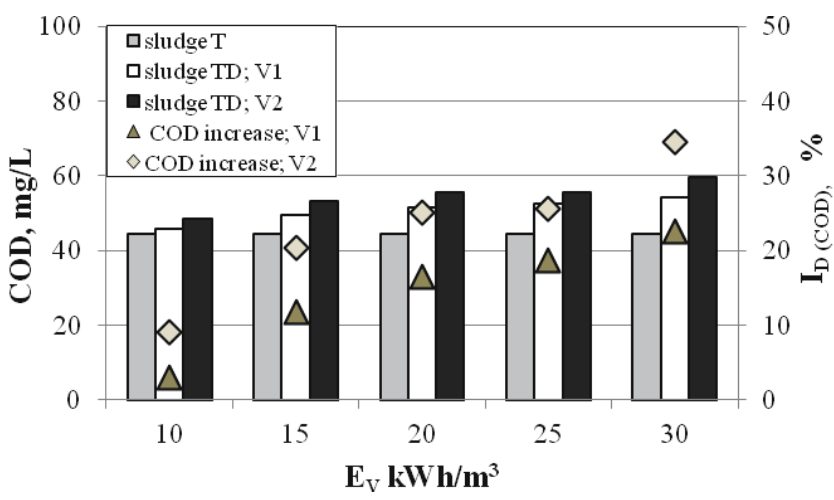

Fig. 4. The influence of energy density on the COD content in the supernatant of thickened sludge after the disintegration process

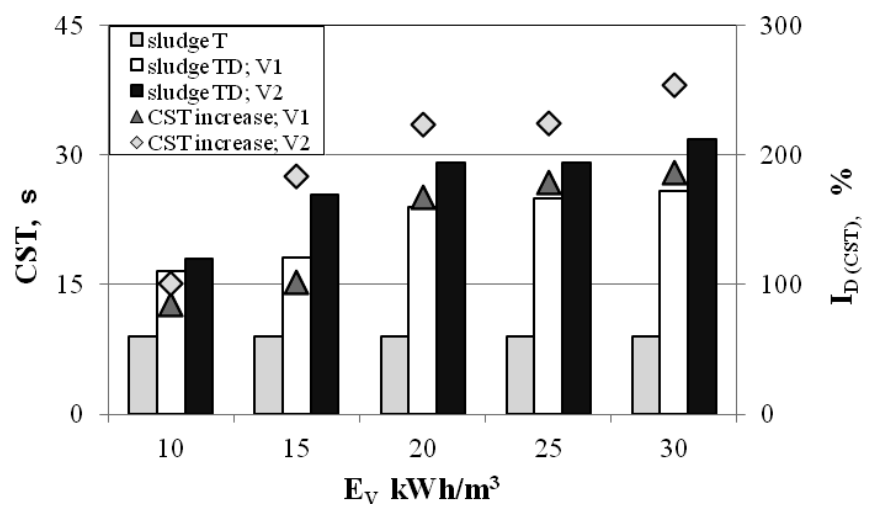

Fig. 6. The influence of energy density on the CST changes in the supernatant of thickened sludge after the disintegration process 
the multiplicity increase in $\operatorname{COD}\left(I_{M(C O D)}\right)$ and $\operatorname{CST}\left(I_{M(C S T)}\right)$ content after the ultrasonic disintegration process are shown in Table 3.

Microscopic analysis revealed that the ultrasonic disintegration of excess sludge results in changes of its structure, which depended on energy amount supplied to the process (Khanal et al. 2006, Feng et al. 2009). This study revealed a breakdown and dispersion of the sludge flocs. The authors found a similar correlation in previous studies (Tytła et al. 2013). The usefulness of the microscopic analysis to the evaluation of disintegration effects was also confirmed by other researchers (Chu et al. 2001, Jiang et al. 2009, Tomczak-Wandzel et al. 2011). Microscopic analysis of excess sludge before (photo A) and after disintegration (photo B) in the most favorable process conditions $\left(E_{V}=30 \mathrm{kWh} / \mathrm{m}^{3}\right.$ and $\mathrm{V}_{2}=1 \mathrm{~L}$ ) are shown in Figs 7 and 8.

Table 3. The changes of $I_{M(C O D)}$ and $I_{M(C S T)}$ indicators values in the process of ultrasonic disintegration

\begin{tabular}{|c|c|c|c|c|}
\hline \multirow{4}{*}{$\begin{array}{l}\text { Energy density } \\
\mathrm{kWh} / \mathrm{m}^{3}\end{array}$} & \multicolumn{2}{|c|}{ Non-thickened sludge } & \multicolumn{2}{|c|}{ Thickened sludge } \\
\hline & \multicolumn{4}{|c|}{$I_{M(i)}$} \\
\hline & $\mathrm{V}_{1}$ & $\mathrm{~V}_{2}$ & $V_{1}$ & $\mathrm{~V}_{2}$ \\
\hline & \multicolumn{4}{|c|}{$I_{M(C O D)}$} \\
\hline 10 & 1.4 & 1.6 & 1.0 & 1.1 \\
\hline 15 & 1.7 & 2.0 & 1.1 & 1.2 \\
\hline 20 & 1.9 & 2.2 & 1.2 & 1.3 \\
\hline 25 & 2.0 & 2.7 & 1.2 & 1.3 \\
\hline \multirow[t]{2}{*}{30} & 2.4 & 3.3 & 1.2 & 1.3 \\
\hline & \multicolumn{4}{|c|}{$I_{M(C S T)}$} \\
\hline 10 & 1.6 & 1.8 & 1.8 & 2.0 \\
\hline 15 & 1.7 & 3.3 & 2.0 & 2.8 \\
\hline 20 & 2.7 & 4.1 & 2.7 & 3.2 \\
\hline 25 & 3.2 & 4.7 & 2.8 & 3.2 \\
\hline 30 & 3.2 & 5.9 & 2.9 & 3.5 \\
\hline
\end{tabular}

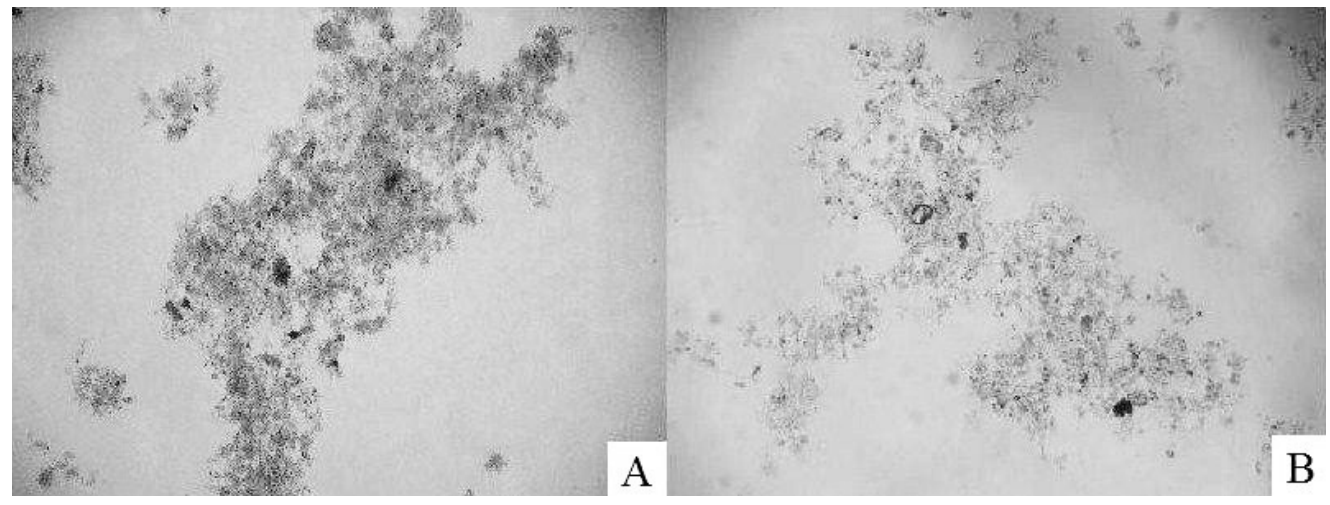

Fig. 7. Microscopic analysis of non-thickened excess sludge (A-non-disintegrated sludge; B-disintegrated sludge)

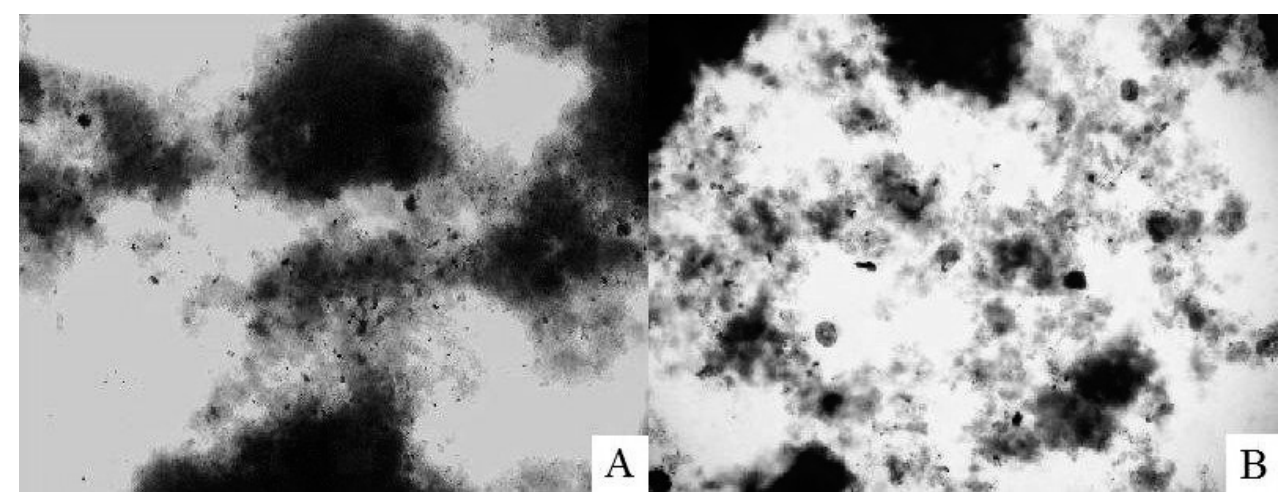

Fig. 8. Microscopic analysis of thickened excess sludge (A-non-disintegrated sludge; B-disintegrated sludge) 


\section{Conclusions}

1. Disintegration of excess sludge in an ultrasonic field influences the changes of its physicochemical characteristics, i.e. content of organic substances dissolved in the sludge supernatant, sludge dewaterability and changes in the flocs structure.

2. The greatest influence on the disintegration effects (obtained as a function of energy supplied to the process) was exerted by the type of sludge, total solids concentration and power density. Higher values of the analyzed disintegration factors, in relation to the initial content of organic substances and a capillary suction time, were obtained for non-thickened sludge characterized by a lower concentration of total solids and power density of $U_{D 2}=0,7 \mathrm{~W} / \mathrm{cm}^{3}$.

3. The study has shown a significant influence of the geometrical proportions on the effects obtained in the sonicated area. It is one of the important aspects in the application of ultrasonic disintegrator devices on a technical scale. The best results were obtained for the sludge samples of $\mathrm{V}_{2}=1 \mathrm{~L}$, with the emitter position of $2.5 \mathrm{~cm}$ from the bottom of the chamber in which the process was carried out.

4. The study has revealed that after the disintegration of examined sludge, an increase in the energy supplied to the process increases the content of COD and CST in the sludge supernatant. The values of the disintegration indicators in relation to $\mathrm{COD}$ in the most favorable conditions of the process were as follows: non-thickened sludge -3.3 and $230 \%$, thickened sludge -1.3 and $35 \%$, for $I_{M(C O D)}$ and $I_{D(C O D)}$, respectively As regards the CST values, the above mentioned indicators were: non-thickened sludge - 5.9 and $493 \%$, thickened sludge -3.5 and $253 \%$ for $I_{M(C S T)}$ and $I_{D(C S T)}$, respectively.

5. The study has shown that for non-thickened sludge, the energy density of $15-25 \mathrm{kWh} / \mathrm{m}^{3}$ was sufficient to achieve a $100 \%$ increase in COD, while for the thickened sludge it should be above $30 \mathrm{kWh} / \mathrm{m}^{3}$.

6. The deterioration in the susceptibility of excess sludge dewaterability, expressed as a rapid increase in the CST values (as a function of energy supplied in the process), was caused by the disintegration of the solid phase and growth in sludge surface area, which was confirmed by the microscopic analysis of the sludge samples.

\section{Acknowledgements}

The research was financed by BK-538/RIE-4/2013.

Ultrasonic disintegrator used in the research was funded by the Grant KBN-N N523 756440.

MSc Malwina Tytła was a scholarship holder of the "Doktoris-Scholarship Program for innovative Silesia" co-financed by the European Union under the European Social Fund.

\section{References}

Bień, J., Stępniak, L. \& Wolny, L. (1995). Ultrasound in water disinfection and preparation of sewage sludge before dewatering, Monograph 37, Publisher Technical University of Częstochowa. (in Polish)
Bień, J. \& Szparkowska, I. (2005). Effect of excess sludge conditioning on the concentration of volatile fatty acids in anaerobic stabilization process, Gaz, Woda i Technika Sanitarna, 7-8, pp. 39-46. (in Polish)

Bougrier, C., Carrère, H. \& Delgenès, J.P. (2005). Solubilisation of waste-activated sludge by ultrasonic treatment, Chemical Engineering Journal, 106, 2, pp. 163-169.

Chen, Y.G., Yang, H.Z. \& Gu, G.W. (2001). Effect of acid and surfactant treatment on activated sludge dewatering and settling, Water Research, 35, pp. 2615-2620.

Chu, C.P., Chang, B.V., Liao, G.S., Jean, D.S. \& Lee, D.J. (2001). Observations on changes in ultrasonically treated waste-activated sludge, Water Research, 35, pp. 1038-1046.

Dewil, R., Baeyens, J. \& Goutvrind, R. (2006). Ultrasonic treatment of waste activated sludge, Environmental Progress, 25, 2, pp. 121-128.

Farooq, R., Rehman, F., Baig, S., Sadique, M., Khan, S., Farooq, U., Rehman, A., Farooq, A., Pervez, A., Mukhtar-ul-Hassan \& Shaukat S.F. (2009). The effect of ultrasonic irradiation on the anaerobic digestion of activated sludge, World Applied Sciences Journal, 6, 2, pp. 234-237.

Feng, X., Lei, H.Y., Deng, J.C., Yo, Q. \& Li, H.L. (2009). Physical and chemical characteristics of waste activated sludge treated ultrasonically, Chemical Engineering and Processing, 48, 1, pp. 187-194.

Fukas-Płonka, Ł. \& Janik, M. (2006). Fermentation of excess sewage sludge, EkoTechnika, 1, pp. 52-56. (in Polish)

Giemza, M. (2013). Ultrasonic disintegration of the sewage treatment plant. The effects of ultrasonic disintegration in practice on several examples of sewage treatment plant, Technologia Wody, 11, pp. 31-35. (in Polish)

Gogate, P.R., Tatake, P.A., Kanthale, P.M. \& Pandit, A.B. (2002). Mapping of sonochemical reactors: review, analysis and experimental verification, AIChE Journal, 48, pp. 1542-1560.

Grönroos, A., Kyllönen, H., Korpijärvi, K., Pirkonen, P., Paavola, T., Jokela, J. \& Rintala, J. (2005). Ultrasound assisted method to increase soluble chemical oxygen demand (SCOD) of sewage sludge for digestion, Ultrasonics Sonochemistry, 12, 1-2, pp. 115-120.

Jiang, J., Yang, S., Chen, M. \& Zhang, Q. (2009). Disintegration of sewage sludge with bifrequency ultrasonic treatment, Water Science \& Technology, 60, 6, pp. 1445-1453.

Khanal, S.K., Isik, H., Sung, S. \& Avan Leeuwen, J. (2006). Ultrasonic conditioning of waste activated sludge for enhanced aerobic digestion, in: Proceedings of IWA Specialized Conference-Sustainable Sludge Management: State of the Art, Challenges and Perspectives, May 29-31, Moscow, Russia 2006.

Kopp, J., Dichtl, N., Müller, J. \& Schwedes, J. (1997). Anaerobic digestion and dewatering characteristics of mechanical disintegrated excess sludge, International Specialized Conference on Sludge Management "Wastewater Sludge-Waste of Resource”, Politechnika Częstochowska, 2, pp. 231-238.

Müller, J. (1996). Mechanical sludge disintegration, Disseration, Shaker-Verlag, Aachen 1996. (in German)

Müller, J., Lehne, G., Schwedes, J., Battenberg, S., Naveke, R., Kopp, J., Dichtl, N., Scheminski, A., Krull, R. \& Hempel, D.C. (1998). Disintegration of sewage sludge and influence on anaerobic digestion, Water Science \& Technology, 38, 8-9, pp. 425-433.

Neis, U., Nickel, K. \& Tiehm, A. (2000). Enhancement of anaerobic sludge digestion by ultrasonic disintegration, Water Science \& Technology, 42, 9, pp. 73-80.

Pilli, S., Bhunia, P., Yan, S., LeBlanc, R.J., Tyagi, R.D. \& Surampalli, R.Y. (2011). Ultrasonic pretratment of sludge: A review, Ultrasonics Sonochemistry, 18, pp. 1-18.

Podedworna, J. \& Umiejewska, K. (2008). Sewage sludge technology, Publishing House of Warsaw University of Technology, pp. 114-115. (in Polish). 
Portenlänger, G. (1999). Mechanical and radical effects of ultrasound, in: Ultrasound in Environmental Engineering, Tiehm, A. \& Neis, U. (Eds.), TU Hamburg - Harburg Reports on Sanitary Engineering, 25, pp. 139-151.

Rai, C.L., Struenkmann, G., Mueller, J. \& Rao, P.G. (2004). Influence of ultrasonic disintegration on sludge growth and its estimation by respirometry, Environmental Science \& Technology, 38, 21, pp. 5779-5785.

Show, K.Y., Mao, T. \& Lee, D.J. (2007). Optimization of sludge disruption by sonication. Water Research, 41, pp. 4741-4747.

Śliwiński, A. (2001). Ultrasound and their application, WNT, Warszawa 2001. (in Polish)

Tabatabaie, F. \& Mortazavi, A. (2008). Studying the effects of ultrasound shock on cell wall permeability and survival of some LAB in milk, World Applied Sciences Journal, 3, 1, pp. 119-121.

Tomczak-Wandzel, R., Mądrzycka, K. \& Cimochowicz-Rybicka, M. (2009). Influence of ultrasonic disintegration on the methane fermentation process. Eds.: Ozonek, J., Pawłowska, M., Monographs Committee of the Polish Academy of Sciences, Environmental Engineering, 1, 58, pp. 331-337, Lublin 2009. (in Polish)

Tomczak-Wandzel, R., Ofverstrom, S., Dauknys, R. \& Mądrzycka, K. (2011). Effect of disintegration pretreatment of sewage sludge for enhanced anaerobic digestion, Environmental Engineering, The 8th International Conference May 19-20, 2011, Vilnius, Lithuania Selected papers, pp. 679-683.

Tiehm, A., Nickel, K. \& Neis, U. (1997). The use of ultrasound to accelerate the anaerobic digestion of sewage sludge, Water Science and Technology, 36, 11, pp. 121-128.

Tiehm, A., Nickel, K., Zellhorn, M. \& Neis, U. (2001). Ultrasonic waste activated sludge disintegration for improving anaerobic stabilization, Water Research, 35, 8, pp. 2003-2009.
Tytła, M., Gnida, A. \& Zielewicz, E. (2013). Changes of excess sewage sludge characteristics in the process of ultrasonic disintegration, Gaz, Woda i Technika Sanitarna 8, pp. 331-336. (in Polish)

Wang, F., Ji, M. \& Lu, S. (2006). Influence of ultrasonic disintegration on the dewaterability of waste activated sludge, Environmental Progress, 25, 3, pp. 257-260.

Zawieja, I. \& Wolny, L. (2011). Effect of Sonicator Power on the Biodegradability of Sewage Sludge, Rocznik Ochrona Środowiska, 13, pp. 1719-1731. (in Polish).

Zawieja, I., Wolny, L. \& Włodarczyk, E. (2013). From sludge to biogas, Chemia Przemystowa, 5, pp. 38-42. (in Polish).

Zhang, G., Zhang, P., Yang, J. \& Chen, Y. (2007). Ultrasonic reduction of excess sludge from the activated sludge system, Journal of Hazardous Materials, 145, 3, pp. 515-519.

Zhang, G., Zhang, P., Yang, J. \& Liu, H. (2008). Energy-efficient sludge sonication: Power and sludge characteristics, Bioresource Technology, 99, pp. 9029-9031.

Zielewicz, E. (2007). Ultrasonic disintegration of excess sewage sludge in obtaining volatile fatty acids, Scientific Papers of Silesian University of Technology, Paper 58, Gliwice 2007. (in Polish)

Zielewicz, E. (2010). Ultrasonic support of excess sludge hydrolysis, Przeglad Komunalny, 12, pp. 74-77. (in Polish)

Regulation of the Minister of Economy of $8^{\text {th }}$ January 2013, concerning the criteria and procedures for admission for the storage of waste in a different type of landfill (Journal of Laws No. 0, item. 38). (in Polish)

National Waste Management Plan 2010, Resolution of the Ministers Council, of a day $29^{\text {th }}$ December 2006, concerning the "National Waste Management Plan 2010”, Polish Monitor 2006 No. 90, item. 946. (in Polish)

\section{Badania wpływu warunków prowadzenia procesu dezintegracji ultradźwiękowej na zmiany charakterystyki fizykochemicznej osadów nadmiernych}

Streszczenie: Dezintegracja ultradźwiękowa jako metoda wstępnej obróbki osadów ściekowych przed procesem stabilizacji, powoduje zmiany charakterystyki fizykochemicznej osadów ściekowych. Celem przeprowadzonych badań było określenie wpływu warunków prowadzenia dezintegracji ultradźwiękowej na zmiany charakterystyki fizykochemicznej nadźwiękawianych osadów, mianowicie: wzrost zawartości substancji organicznych w cieczy osadowej, podatność osadów na odwadnianie oraz stopień rozdrobnienia fazy stałej osadów (strukturę kłaczków osadu). Nadźwiękawianiu poddawano osady nadmierne niezagęszczone i zagęszczone, pochodzące $\mathrm{z}$ komunalnej oczyszczalni ścieków w Gliwicach. Proces prowadzono przy użyciu dezintegratora o wysokiej mocy, wyposażonego $\mathrm{w}$ głowicę soczewkową. W celu określenia najkorzystniejszych warunków prowadzenia procesu osady ściekowe poddawano nadźwiękawianiu falą o częstotliwości $\mathrm{f}=25 \mathrm{kHz}$ w funkcji czasu, przy zmiennej geometrii w obszarze nadźwiękawiania (odległości emitera od dna komory, w którym nadźwiękawiano osady) i różnej objętości prób tj. $\mathrm{V}_{1}=0,5 \mathrm{i} \mathrm{V}_{2}=1 \mathrm{~L}$, przy położeniu emitera kolejno 1 i $2,5 \mathrm{~cm}$ od dna naczynia, w którym nadźwiękawiano osady. Dezintegrację osadów prowadzono w określonym zakresie gęstości energii $\left(E_{V}\right)$, tj. od $10 \mathrm{do} 30 \mathrm{kWh} / \mathrm{m}^{3}$. Oceny efektów dezintegracji dokonano w oparciu o zmiany charakterystyki fizykochemicznej badanych osadów i/lub cieczy osadowych po zakończeniu procesu, wyrażonych przy pomocy powszechnie stosowanych oraz własnych wskaźników efektów dezintegracji. Najlepsze efekty dezintegracji uzyskano dla osadów o objętości $\mathrm{V}_{2}=1 \mathrm{~L}$ i położeniu emitera $\mathrm{w}$ odległości $2,5 \mathrm{~cm}$ od dna naczynia, $\mathrm{w}$ którym prowadzono proces. Przeprowadzone badania potwierdzają, iż w różnych warunkach prowadzenia dezintegracji ultradźwiękowej osadów nadmiernych można uzyskać odmienne jego efekty, co może wpływać na przebieg stabilizacji beztlenowej osadów oraz jakość produktów końcowych tego procesu. 